\title{
MHC class I immune evasion in MCMV infection
}

\author{
Carmen M. Doom · Ann B. Hill
}

Received: 4 February 2008 / Published online: 11 March 2008

(C) Springer-Verlag 2008

\begin{abstract}
Murine cytomegalovirus (MCMV) is a wellstudied model of natural $\beta$-herpesvirus infection. However, many questions remain regarding its control by and evasion of the immune response it generates. CD8 and CD4 T cells have both unique and redundant roles in control of the virus that differ based on the immunocompetence of the infected mice. MCMV encodes major histocompatibility complex (MHC) class I immune evasion genes that can have an impact in vitro, but their role in infection of immunocompetent mice has been difficult to identify. This review addresses the evidence for their in vivo function and suggests why they may be evolutionarily conserved.
\end{abstract}

Keywords MCMV $\cdot$ MHC class I $\cdot$ Immune evasion · Natural infection $\cdot$ CD8 T cell control

\section{Introduction}

Genes that target the MHC class I pathway of antigen presentation are a common feature of herpesviruses. The real evolutionary role of these genes, however, is not as clear as was originally supposed. In this article we will review the data concerning the function of these genes in vivo, in the murine CMV model, which is where they have been most studied. To put this in context, we will first summarize the natural history of MCMV infection and its immune control

C. M. Doom · A. B. Hill $(\square)$

Department of Molecular Microbiology and Immunology, Oregon Health and Science University,

3181 SW Sam Jackson Park Road,

Portland, OR 97239, USA

e-mail: hillan@ohsu.edu and then proceed to a review of the role in which MHC class I immune evasion plays.

\section{MCMV infection and the resulting immune response}

Murine cytomegalovirus (MCMV), a $\beta$-herpesvirus, has been used to model CMV infection and immunobiology for over 40 years. Particular strengths of this model include its status as a natural pathogen of mice, as well as the relative ease of manipulating mice and the power of mutant mouse strains.

MCMV was first recovered and propagated in vitro in 1954 [1]. Between 60 and $90 \%$ of mice are infected in the wild - similar to the prevalence of HCMV in humans - and $\sim 34 \%$ of mice are infected with multiple isolates [2-5]. Human CMV is commonly transmitted via infectious secretions (including saliva, urine, and breastmilk), across the placenta, or by solid organ transplant. The natural routes of infection of mice have not been definitively established. Mice do not transmit MCMV across the placenta, but horizontal and vertical transmission is common, likely via saliva and/or breastmilk [2, 4, 6, 7]. Thus, it has been speculated that the oral (p.o.), intranasal (i.n.), and subcutaneous (s.c.) routes (due to biting behavior) are the most likely natural routes.

The immune response to MCMV has been well studied over the past four decades, although the complexity and redundancy of this response have certainly raised many new questions. In a laboratory setting, MCMV and the resulting immune response have historically been studied in BALB/c mice using high dose infection $\left(\geq 10^{5}\right.$ plaque forming units (pfu)) of tissue culture (TC)-passaged virus (Smith strain) by either an intraperitoneal (i.p.) or s.c. footpad inoculation. Our and other laboratories have more 
recently advanced the C57BL/6 (B6) mouse model, in large part because of the wealth of tools available for this strain (transgenic and knockout animals, epitope characterization, etc.).

\section{Pathogenesis}

MCMV infection is characterized by three stages: (a) acute infection, whereby visceral organ virus titres peak at day three to five post-infection (p.i.) and the CD8 $\mathrm{T}$ cell response peaks at day seven p.i. (b) persistent infection, whereby virus is generally controlled in the visceral organs, but titres peak in the salivary glands (c) and latent infection, whereby limited viral gene expression can be detected by RT-PCR, but infectious virus is only sporadically produced and detectable by plaque assay or in vitro reactivation assays [8-10].

Upon i.p. infection of $\mathrm{BALB} / \mathrm{c}$ or $\mathrm{B} 6$ mice, the virus acutely replicates in multiple sites, including the spleen, liver, adrenal glands, lung, and salivary glands. Initial studies on the pathogenesis of infection of immunocompetent, adult BALB/c mice reported the kinetics and magnitude of viral titres in the spleen, liver, and salivary glands after i.p. infection with high dose, salivary gland-derived (SGderived), Smith strain MCMV. Virus peaks in the spleen and liver around day four p.i., drops to the limit of detection by day nine, and then recurs at a lower titre a few weeks later [11]. The virus infects many cell types, but epithelial cells, endothelial cells, and macrophages are especially important sites of virus production.

Virus in the salivary glands develops with slower kinetics, peaking at day nine p.i, and then gradually declining until it is no longer detectable at day 32 p.i. The titres here reach a two to three log higher peak than in the spleen or liver. Importantly, the salivary glands are the central organ for replication and transmission. MCMV specifically infects the acinar glandular epithelial cells of this organ [12].

The pathogenesis is somewhat different with TC-passaged virus infection of adult BALB/c mice. The titres in the salivary glands and lungs are the highest in acute infection [13]. By 2 weeks p.i., there is no detectable virus by plaque assay in the lung, liver, or spleen; the only site in which virus is found is the salivary glands, where it peaks around 3 weeks p.i. and becomes undetectable by 2 months $[13,14]$. Control of acute infection and persistence in the salivary glands is different in mice infected as neonates, which is discussed in more detail below. Overall, the differences seen between SG- and TC-derived viruses are attributed to differences in purity, virulence, and the inflammatory response induced by SG-derived viruses.

Latent MCMV DNA is found in many organs, including the salivary glands, adrenal glands, spleen, heart, kidney, and lungs. The lungs have been reported to be a particularly important latent virus reservoir; lung viral titres are high in acute infection and reactivating viral loads are higher here than other organs, correlating reactivation with the acute viral load [13]. The specific cell types involved in latency had been theorized for some time; it was assumed that the cells important in HCMV latency would also be important for MCMV. This has held true, in general, as bone marrow (BM) and alveolar cells of the monocyte lineage and endothelial cells are reported sites of MCMV latency [10, 15, 16].

Our laboratory has focused on the B6 model of MCMV infection, using high dose, i.p. infection with TC-derived Smith strain. Virus can be detected by plaque assay in the spleen, lung, liver, kidney, and heart at 4 days p.i., although not consistently in all mice (unpublished data). Virus in the salivary glands is found by plaque assay consistently up to 2 weeks p.i. [17]. By quantitative PCR analysis, virus peaks in the lung, kidney, and liver around day four, and is detectable through day 15 p.i. [18]. During chronic infection of B6 mice, virus cannot usually be detected by plaque assay in any organ.

\section{Natural killer cells}

Natural killer (NK) cells are important in the first 45 days p.i., at which point the adaptive immune response begins to contribute. The NK cell response accounts for a distinct difference between the immune response of B6 and $\mathrm{BALB} / \mathrm{c}$ mice. BALB/c mice are considered to be MCMV "susceptible," while B6 mice are "resistant," due to a difference in their Ly49H status. B6 mice express Ly49H, an activating NK cell receptor that recognizes the $m 157$ gene product of MCMV [19, 20]. Expression of this viral protein activates Ly49H on NK cells, leading to the lysis of infected cells and, thus, more robust NK cell control in B6 mice [21, 22]. Ly49H ${ }^{-}$strains (129/J, BALB/c, etc.) are much more susceptible to MCMV infection because they lack this activation. One of the biggest differences in viral titres between resistant and susceptible mice is found in the spleen; titres are at least three logs higher in BALB/c and congenic BALB.B mice than B6 mice for the first 6 days p.i $[23,24]$ (see also the contribution by Lenac et al. in this issue of MMI). In fact, removing the spleens of $\mathrm{BALB} / \mathrm{c}$ mice confers resistance, signifying the importance of virus replication in this organ [25]. BALB/c and 129/J mice can succumb to high dose, i.p. infection, while B6 mice infected i.p. with up to $5 \times 10^{6}$ pfu show no signs of morbidity. Furthermore, restoring NK cell function to BALB/c mice makes them more "resistant" [26-29], while blocking or inhibiting NK cell function in B6 mice makes them more "susceptible" [24, 30-32]. 
Antibody

Control of acute, primary MCMV infection is independent of an anti-MCMV antibody response [17, 33]. Control of the latent virus pool is also independent of antibody, and antibody does not provide protection from superinfection with different strains of MCMV [5, 7]. However, prophylactic antibody treatment via transfer of serum or induced by vaccination with inactivated virus or recombinant glycoproteins offers protection [34-38].

Antibody is thought to play a role either in limiting viral reactivation or limiting replication after reactivation, however [13]. This was determined, in part, by studying chronically infected B cell-deficient $(\mu \mathrm{MT} / \mu \mathrm{MT})$ mice, immunosuppressed by irradiation and depletion of $\mathrm{T}$ and NK cells. Virus starts to reappear in the salivary glands 3 days after immunosuppression [39]. Two weeks after immunosuppression, B cell-deficient mice have spleen, lung, and salivary glands viral titres that are two to three logs higher than B6 controls [17, 39]. This is reversed by treating the mice with anti-MCMV sera.

T cell control of MCMV in immunocompetent, adult mice

\section{$B A L B / c$}

While there are significant differences in the innate immune response to MCMV in B6 and BALB/c mice (i.e. NK cell control), the adaptive immune response is very similar. The role of $\mathrm{T}$ cells in MCMV infection of immunocompetent mice has been studied by depleting lymphocyte subsets, either alone or in combination. Particularly interesting findings to come out of these experiments are that: when mice are CD4 $\mathrm{T}$ cell depleted before infection and CD8 T cells are then depleted after long-term infection has been established, $100 \%$ of mice have virus in both their lungs and salivary glands at 10 weeks p.i., implying a role for CD8 T cells in the absence of the CD4 subset [40]. Depletion of CD4 $\mathrm{T}$ cells alone results in uncontrolled virus in the salivary glands in acute infection [40]. The requirement for CD8 T cells is less dramatic; antibody depletion of CD8 T cells results in only a modest impact on the acute control of virus in the lung [41]. This suggests that CD4 T cells educated in the absence of CD8 T cells acquire new and compensatory functions. This data leads to several conclusions: first, although CD8 $\mathrm{T}$ cells are not absolutely required to control infection, they play an important role in normal mice. Second, CD8 T cells educated in the absence of CD4 $\mathrm{T}$ cells cannot control virus in the salivary glands, while CD4 $\mathrm{T}$ cells primed in an environment lacking CD8 T can [40-42]. Finally, CD4 T cell help is not required for priming a CD8 $\mathrm{T}$ cell response or for immediate maintenance of CD8 T cell memory, although it is required for the develop- ment of antibody [41]. CD4 T cells may also be needed for long-term maintenance of the CD8 $\mathrm{T}$ cell response in MCMV infection, but their exact role in this is not yet clear.

\section{$C 57 B L / 6$}

There is relatively less literature on $\mathrm{T}$ cell subset control in B6 mice, in large part due to their robust NK cell response. We now know, however, that the overall picture in B6 mice is the same as in BALB/c mice: CD8 T cells are rather dispensable for control of MCMV in immunocompetent mice. When the C57BL substrain, C57BL/10 mice, are depleted of $\mathrm{T}$ cell subsets, either alone or in combination, then infected i.p. with high dose, SG-derived MCMV (K181 strain), there is no effect on the virus titres in the spleen or liver [29]. When C57BL/6 mice are depleted of these subsets and infected with high dose, s.c., TC-derived Smith MCMV, CD4 depletion results in impaired control of virus in the salivary glands at 3 weeks p.i., while CD8 depletion has no effect [17]. A landmark study of cell subset depletion in chronically infected, antibody-deficient mice indicated that CD4 and CD8 T cells, as well as NK cells, all contribute to control of latent virus in a redundant fashion. Depletion of any two of these cell types leads to detectable virus reactivation within days, whereas depletion of any single subset does not [39].

$\mathrm{T}$ cell control of MCMV in immunosuppressed, adult mice

The accumulated data thus indicate that there is a high degree of redundancy in immune control mechanisms of MCMV, no doubt a result of 70 million years of co-evolution to achieve a highly buffered equilibrium between the virus and its host. The fact that no single arm of the immune system is uniquely required for virus control does not mean that each of these arms is ineffectual, merely that if it is absent, it can be compensated for by another arm. To understand the capability of each immune component against MCMV, it has been necessary to study severely immunocompromised hosts and to selectively add back each component. This has been done by developing a bone marrow transplant model of MCMV infection, which also serves to model clinical CMV disease in transplant and immunosuppressed patients.

\section{$B A L B / c$}

The most commonly used model, developed by the Reddehase group, involves irradiated BALB/c "indicator" mice and the transfer of different subsets of primed lymphocytes, either at the time of or 6 days after infection with high dose, s.c., TC-derived Smith MCMV [14]. Irradiated, BALB/c mice that are infected with MCMV without any hematopoietic cell 
transfer unfailingly succumb to lethal CMV disease. There is infection of the liver, lung, spleen, kidney, adrenal glands, gastrointestinal tract, and salivary glands, both evidenced by virus found in these organs and histopathology seen by immunohistochemistry (IHC) and by in situ hybridization (ISH) [14, 40, 43, 44].

Irradiated mice can be rescued from lethal disease, however, by the transfer of lymphocytes, specifically CD8 T cells, from acutely or chronically infected mice [14, 40, 45]. This rescue is dependent on the number and type of cells transferred and results in decreased organ virus titres. By two weeks after lymphocyte transfer, titres in the spleen, liver, and lung are below detection and titres in the salivary glands decrease by greater than two logs [14, 40]. Depleting CD4 T cells from the transferred cells has little effect on control of infection and none on the prevention of lethal disease [14, 45]. Transferring CD8 T cells alone is as effective in reducing lung, adrenal gland, and spleen titres as transferring both subsets [40, 41, 43, 45, 46]. Depleting CD8 T cells, however, or CD4 and CD8 T cells, results in organ immunopathology, virus replication in all organs tested, and $100 \%$ lethality [40, 45]. Thus, in contrast to the unique role for $\mathrm{CD} 4 \mathrm{~T}$ cells seen in immunocompetent mice, when mice are severely immunocompromised, CD8 $\mathrm{T}$ cells are both necessary and sufficient to control MCMV infection and to decrease histopathology.

\section{$C 57 B L / 6$}

Fewer studies have been reported regarding the immune response to MCMV in immunosuppressed $\mathrm{B} 6$ mice; this strain is not routinely used by the Reddehase group. Holtappels et al. [47] reported, however, that adoptive transfer of CD8 T cells specific for the $\mathrm{D}^{\mathrm{b}}$-restricted M45 MCMV epitope, HGIRNASFI, does not impact the virus titres in the spleen or lung, nor does it impact the number of infected liver cells at 12 days p.i.

\section{Virus control in neonates}

Human intrauterine infection is a major cause of HCMV morbidity. As mentioned above, MCMV does not cross the placenta, but vertical transmission occurs, which is proposed to be via the breastmilk. For this reason, MCMV infection of neonates is an important area of study for those interested in natural, biologically relevant infection. There is still much to be learned, however, about the route of spread to pups and about the immune response in young mice. Much of the original work looking at MCMV infection of young mice addressed survival rates and susceptibility compared to adults. Neonatal mice of a variety of strains have a much lower lethal dose ${ }_{50}\left(\mathrm{LD}_{50}\right)$ than weanling or adult mice. For example, the $\mathrm{LD}_{50}$ in newborn BALB/c mice infected i.p. with the K181 strain is only two pfu, while it is $5 \times 10^{4}$ in adult BALB/c mice $[48,49]$. Furthermore, neonatal BALB/c mice have decreased survival, higher viral titres in the spleen, salivary glands, and lung, and delayed clearance when compared to adults [13]. These findings are the most pronounced in the salivary glands. It has been suggested that newborn mice of all strains can be considered MCMV susceptible; resistance to infection develops in the first few weeks of life [50]. In comparing strains of mice, Shellam et al. [21, 51] have reported that one-day-old $\mathrm{BALB} / \mathrm{c}$ pups have higher virus titres in the spleen and liver than the more resistant CBA strain.

Some groups became interested in what cell types were involved in the neonatal immune response. Adoptive transfer of adult splenocytes one day after i.p. infection of B6 neonates with high dose, SG-derived Smith MCMV leads to decreased viral titres in the spleen and a benefit in survival [52]. There is little benefit from splenocytes transferred from 17-day-old mice, but intermediate benefit from splenocytes transferred from five week-old-mice. When T cells are depleted from the transferred splenocytes, there is still a survival advantage, but when NK cells are depleted, there is no protection and increased viral titres in the spleen. The importance of NK cells in offering protection to neonates was verified by observing the protective effect upon transfer of cloned NK cells.

In another study using 12-hour-old BALB/c pups, mice were infected i.p. with low dose (100 pfu) TC-derived Smith MCMV [53]. There is high titre virus in the spleen and lung eight days p.i., which correlates with the time at which they begin to succumb to the virus. When CD4 and CD8 $T$ cells are depleted from four-day-old pups, the titres in the lung increase by about one log. The results are nearly identical in B6 pups of the same age. When the specific role of CD8 T cells was evaluated in $\mathrm{CD} 8^{-1-}$ neonates, titres in the lung are again about one log higher than in WT B6 mice [53].

\section{Introduction to MHC I immune evasion in MCMV}

The evolution of the CMVs has resulted in exquisite host adaptation and the development of sophisticated immune evasion mechanisms. Our lab is interested in MCMV-mediated major histocompatibility complex (MHC) class I immune evasion. MCMV encodes three known genes that interfere with antigen presentation through the MHC class I pathway: $m 4, m 6$, and $m 152$. The proteins either prevent the peptide-MHC class I complex from reaching the cell surface or associate with the complex at the surface of infected cells. $\mathrm{m} 6$ redirects MHC class I molecules to the lysosome [54], while m152 retains MHC class I molecules 
in the ER-Golgi intermediate compartment (ERGIC) [55]. Expression of either one, or both, of these proteins results in downregulation of cell-surface MHC class I molecules [56-58]. The mechanism by which $\mathrm{m} 4$ acts is not known, however, $\mathrm{m} 4$ forms complexes with MHC class I molecules, which are exported and stay stably associated for many hours on the cell surface. Unlike $\mathrm{m} 6$ and $\mathrm{m} 152$, expression of $\mathrm{m} 4$ does not lead to decreased cell surface expression of MHC class I; rather, it may even lead to increased levels [56].

Because of the evolutionary conservation of the MHC class I immune evasion genes and because CD8 T cell control has been shown to be important in the bone marrow transplant model, it became a pressing question to determine the impact of these genes on CD8 T cell function. These experiments were made possible by using knockout viruses that lacked one or more of the MHC class I immune evasion genes $[53,56]$.

\section{In vitro data comparing WT-MCMV and MHC class I immune evasion mutants}

As MCMV MHC class I-restricted antigens were individually identified, it became rather straightforward to study the effector function of MCMV-specific CD8 T cells in vitro [59-63]. A number of studies have shown that MCMV-specific CD8 T cells can kill cells infected with a mutant virus lacking one or more of the MHC class I immune evasion genes, but not cells infected with WT-MCMV [18, 53, 55, $57,59,64,65]$. It should be noted that most comparisons between mutant and WT-MCMV infection utilize a WTBAC MCMV, which was generated using the Smith strain and bacterial artificial chromosome (BAC) technology [56]. The phenotype is not subtle; using infected IC-21 targets (a macrophage-like transformed cell line), Pinto et al. [58] demonstrated that 16 different MCMV peptide-driven CD8 $\mathrm{T}$ cell lines can kill cells infected with a virus lacking all three MHC class I immune evasion genes $(\Delta \mathrm{m} 4+\mathrm{m} 6+$ m152-MCMV) but cannot kill WT-MCMV infected cells. This finding has also been repeated using primary macrophages infected with $\Delta \mathrm{m} 4+\mathrm{m} 6+\mathrm{m} 152-$ or WT-MCMV [58]. Similar findings have also been reported using infection with different MHC class I immune evasion gene mutant viruses [47, 53, 65-67].

It should be noted, however, that this phenotype is not absolute. Koszinowski's group has reported that IE1-specific CD8 T cells from BALB/c mice can kill WT-MCMV infected mouse embryonic fibroblasts, primary macrophages, and transformed macrophages [66, 68]. Our laboratory also has evidence that CD8 $\mathrm{T}$ cells of some specificities can kill primary dendritic cells or macrophages infected with WT-MCMV (data not shown) [63]. The full implications of these results remain to be explored. However, when WT-MCMV and immune evasion mutants have been compared side by side, killing of mutant virusinfected cells is invariably more efficient.

\section{In vivo data comparing WT-MCMV and MHC class I immune evasion mutants}

While in vitro experiments are important in delineating the functions of individual genes, the ultimate test is what happens in vivo. Before discussing CD8 $\mathrm{T}$ cell control, however, a second biological function for $m 152$ must be mentioned. In addition to its MHC class I immune evasion function, m152 also impacts NK cell control in BALB/c mice by downregulating expression of RAE-1 ligands for the activatory receptor, NKG2D [26]. Therefore, when $\mathrm{BALB} / \mathrm{c}$ mice are infected with m152-expressing WTMCMV, they lack NK cell activation both by the Ly49H and NKG2D receptors. m152 does not impact NKG2D receptor-mediated activation in B6 mice [26], thus in WTMCMV infection of these mice, activation via $\mathrm{Ly} 49 \mathrm{H}$ and NKG2D is intact. NK cell function can be somewhat restored by infecting BALB/c mice with $\triangle \mathrm{m} 152-\mathrm{MCMV}$ (i.e. the activatory receptor ligand is no longer downregulated). Under these conditions, the virus is better controlled by NK cells, as evidenced by lower titres in the lungs in the first few days of infection [26]. Because NK cell control of mutant virus could contribute to any differences seen between WT-MCMV and mutant virus infection, the cell type(s) responsible have needed to be identified by specific antibody deletions.

Immunocompromised BALB/c mice

As described above, because of the redundancy in immune control of MCMV, the antiviral potential of $\mathrm{T}$ cells has been best demonstrated in immunocompromised mice. Accordingly, the impact of the MHC I immune evasion genes on $\mathrm{T}$ cell control of virus is also most clearly seen in immunocompromised animals, which have been manipulated so that the burden of control falls most heavily on CD8 T cells.

When irradiated mice infected with either $\Delta \mathrm{m} 152$ MCMV or a revertant (WT phenotype) virus receive transferred lymphocytes isolated from the spleens of latently infected mice, $\triangle \mathrm{m} 152-\mathrm{MCMV}$ is always better controlled in the lungs at two weeks p.i. [53]. In the liver, transfer of non-primed lymphocytes completely controls $\Delta \mathrm{m} 152-$ MCMV, but not WT virus; when primed cells are transferred, both viruses are completely controlled. This was the first in vivo evidence that the immune evasion gene, $m 152$, has an impact on CD8 T cell control. 
Immunocompromised C57BL/6 mice

B6 mice have also been used in the model of hematoablation by $\gamma$-irradiation. The role of $\mathrm{m} 152$ was tested by comparing organ virus titres between WT- and $\triangle \mathrm{m} 152-\mathrm{MCMV}$ infection after transfer of $\mathrm{D}^{\mathrm{b}}$-restricted M45-specific CD8 T cells-both peptide-driven lines or memory cells taken directly ex vivo [47]. In the spleen, transfer of low numbers of M45 ( $\left.\mathrm{D}^{\mathrm{b}}\right)$-specific CD8 $\mathrm{T}$ cells completely controls $\triangle \mathrm{m} 152$ - but not WT-MCMV at 12 days p.i. In the lung, there is over a two log decrease in $\Delta \mathrm{m} 152$ virus titres, dependent on the number of transferred cells. In the liver, instead of looking at organ titres, a very elegant two-color ISH technique was used after co-infection of B6 mice with mutant and revertant virus. Liver sections are stained for virus and the readout for $\triangle \mathrm{m} 152-\mathrm{MCMV}$ infection is red and for WT-MCMV, black. Thus, infected cells can be individually visualized and the infecting virus identified. M45 ( $\left.\mathrm{D}^{\mathrm{b}}\right)$-specific cells can again kill cells infected with $\triangle \mathrm{m} 152-\mathrm{MCMV}$, but have no impact on the cells infected with WT virus. At the highest number of cells transferred, the number of $\triangle \mathrm{m} 152-\mathrm{MCMV}$ infected cells in the liver is at the limit of detection. In another set of experiments by Holtappels et al. [57] using the same model, a $\Delta \mathrm{m} 4+\mathrm{m} 6$ MCMV mutant could not be controlled in the lung or the liver by M45 ( $\left.\mathrm{D}^{\mathrm{b}}\right)$-specific CD8 T cells, but a $\Delta \mathrm{m} 6$ mutant could with graded numbers of transferred cells. These studies suggest that $\mathrm{m} 152$ is the principal negative regulator of antigen presentation, that $\mathrm{m} 4$ is a positive regulatorrestoring presentation in the face of $\mathrm{m} 152$ expression-but that $\mathrm{m} 6$ (which is present in all wild isolates) [69] can overrule the positive effect of $\mathrm{m} 4$.

Immunocompetent C57BL/6 and BALB/c mice

\section{CD8 $T$ cell response}

The MHC class I immune evasion genes allow virus to escape otherwise stringent CD8 T cell control in severely immunocompromised mice when adoptively transferred CD8 $\mathrm{T}$ cells are, in effect, the only functioning arm of the immune system. There has been rather little evidence, however, for a phenotype of these genes in WT-MCMV infection of immunocompetent mice.

The first surprising finding was that $\mathrm{BALB} / \mathrm{c}$ and $\mathrm{B} 6$ mice mount strong and virtually identical acute CD8 T cell responses to WT and $\Delta \mathrm{m} 4+\mathrm{m} 6+\mathrm{m} 152-\mathrm{MCMV}[47,59$, 70]. This was particularly surprising given the molecularly robust MHC class I downregulation in WT-BAC infected cells and the impact on cytotoxicity in vitro and in vivo. These results have led to a presumption that the CD8 T cell response to MCMV must be primed in vivo by cross-presented antigen, although this remains to be verified.
However, the real question of interest in evolutionary terms is how the immune evasion genes impact viral fitness. Two types of readout have been used to identify a potential role of the MHC class I immune evasion genesone involves using the CD8 $\mathrm{T}$ cell response as a proxy for virus activity and the second involves measuring virus activity itself by plaque assay or IHC/ISH. The CD8 T cell response to some MCMV epitopes increases over time and the cells acquire an effector memory $\mathrm{T}$ cell phenotype [71], a phenomenon later dubbed "memory inflation" [72, 73]. The size and phenotype of the CD8 $\mathrm{T}$ cell response in chronic infection may be the best indicator of virus activity. However, there is a nearly identical CD8 T cell phenotype and response between chronic infection of $\mathrm{B} 6$ mice with WT-BAC MCMV, $\triangle \mathrm{m} 152-\mathrm{MCMV}$ and $\triangle \mathrm{m} 4+\mathrm{m} 6+$ m152-MCMV [18, 59, 74]. The CD8 $\mathrm{T}$ cell response to both WT- and $\triangle \mathrm{m} 4+\mathrm{m} 6+\mathrm{m} 152-\mathrm{MCMV}$ in acute and chronic infection is also the same in BALB/c mice [75] (data not shown). Thus, the ongoing immune response gives no sign that there is any difference in the activity of WT-or mutant MCMV during latent infection.

Might the MHC class I immune evasion genes not affect the global CD8 $\mathrm{T}$ cell response, but still impact viral control? Finally, the answer, in some circumstances is, "Yes."

\section{Viral control}

Immunocompetent BALB/c mice infected i.p. with high dose TC- or SG-derived $\Delta \mathrm{m} 4+\mathrm{m} 6+\mathrm{m} 152-\mathrm{MCMV}$ control the virus in the salivary glands more effectively than WT-MCMV between two and four weeks p.i. [76]. Importantly, the difference in virus control is CD8 T cell-dependent, as anti-CD8 antibody depletion equalizes the titres. This is key in vivo evidence that the MHC class I immune evasion genes do benefit the virus in the face of a fully intact, functional immune system - at least in the salivary glands, the site of viral dissemination.

In immunocompetent B6 mice, no differences have been detected in the virus genome copy number between infection with WT-MCMV and $\triangle \mathrm{m} 4+\mathrm{m} 6+\mathrm{m} 152-\mathrm{MCMV}$. This was determined in the lung, liver, and kidney between days zero and 14 p.i.; the viruses show the same kinetics in these organs and all peak around three to five days p.i. [18]. In our hands, we rarely find any virus in the salivary glands of B6 mice by plaque assay.

\section{Neonates: BALB/c and C57BL/6}

Interestingly, the first report of the function of the $\mathrm{MHC}$ class I immune evasion genes described infection in neonates, in both BALB/c and B6 pups. BALB/c pups were infected i.p. with low dose virus at 12 hours of age [53]. Their survival and organ viral titres were measured, and at 
day eight p.i., $\triangle \mathrm{m} 152-\mathrm{MCMV}$ is better controlled in the lungs and spleen than revertant, WT-MCMV. This translates into a survival difference: mice infected with WTMCMV have much lower survival rates through day 30 p.i. In slightly older, four-day-old BALB/c pups, $\Delta \mathrm{m} 152-$ MCMV is again better controlled than WT-MCMV in the lungs at day 10 p.i. When CD4 and CD8 T cells are depleted, the titres increase and equalize, implicating a role for $\mathrm{T}$ cell control. In four-day-old B6 pups infected under the same conditions, lung titres at day 10 p.i. are also lower in $\triangle \mathrm{m} 152-\mathrm{MCMV}$ infection, and this difference is abrogated with CD4 and CD8 T cell depletion [53]. Since infection of neonates is likely an important means of virus transmission in the wild, the ability of immune evasion to impact infection in this setting probably has real biological significance.

\section{Natural infection model}

We thus know two settings in which MHC class I evasion genes have a phenotype in vivo in immunocompetent mice: in neonates and in the salivary glands. Both of these could offer clear selective advantage to the virus. However, the phenotype is rather mild, and does not necessarily justify the striking evolutionary conservation of these genes. This consideration caused us (and others) to ask: are there other biologically relevant conditions under which the MHC class I immune evasion genes have a phenotype in vivo? In order to dissect mechanisms of immune control and evasion in vivo, it has been important to use high dose and systemic infection for establishing a reproducible model. These conditions do not model natural infection, however, which is likely not such a high inoculating dose and is certainly not delivered by an i.p. route.

We and others have therefore hypothesized that a global role for the MHC class I immune evasion genes may be unmasked in lower dose infection by more natural routes. High dose infection may simply overwhelm the system, providing enough antigen for CD8 $\mathrm{T}$ cells to become activated even in the face of MHC class I immune evasion. At low infecting doses, WT-MCMV may be better able to establish infection due to its immune evasion abilities, which would be clear if more mice became infected with WT- than $\Delta \mathrm{m} 4+\mathrm{m} 6+\mathrm{m} 152-\mathrm{MCMV}$ at limiting doses. Another possibility is that, given the likely lower latent virus burden, WT-MCMV may be more successful at reactivating from latency under these conditions; this would be evidenced by a higher CD8 $\mathrm{T}$ cell response and/or higher titres of virus in the salivary glands at chronic time points.

We set out to explore this idea in two different ways. The first was to infect adult BALB/c and B6 mice with low doses of WT- or $\Delta \mathrm{m} 4+\mathrm{m} 6+\mathrm{m} 152-\mathrm{MCMV}$ by potentially natural routes (i.n., s.c.) or i.p. We used the i.p. route as a positive control, as we know we can establish infection at low doses. The second approach was to orally infect BALB/c neonates with WT- or $\Delta \mathrm{m} 4+\mathrm{m} 6+\mathrm{m} 152$ MCMV. Only the oral route was used here assuming vertical transmission is via the breastmilk and/or saliva. The same virus preparations of TC-derived, WT- or $\Delta \mathrm{m} 4+\mathrm{m} 6+\mathrm{m} 152-\mathrm{MCMV}$ were used for all of the following experiments. Quantitative PCR verified that the particle-to-pfu ratio was similar for both viruses (data not shown). While it can be argued that SG-derived virus may be more virulent and thus, natural, we also reasoned that mice are not infected in the wild with a salivary glands homogenate. Infecting with a wild MCMV isolate or a more virulent lab strain would have been preferred for modeling natural infection, but that comparison is not yet possible, as no MHC class I immune evasion mutant of a wild isolate has been made. With that limitation, a first set of dose-titration experiments were performed to determine the lowest dose via each route at which infection could be detected in some, but not all, of the mice.

We approached the question using multiple measurements of infection: (a) viral titres in the salivary glands to most directly measure viral control of WT- and $\Delta \mathrm{m} 4+\mathrm{m} 6+\mathrm{m} 152-\mathrm{MCMV}$ (b) the CD8 T cell response to establish that infection occurred and to use as a proxy measurement of viral activity (c) an antibody response, also for evidence of established infection. Based on one or more of these parameters, the threshold of infection by the i.p., s.c., and i.n. routes was between 100 and 1,000 pfu (data not shown). The following experiments were designed to detect differences in the immune response expecting fairly low variance within the groups and, importantly, between repeat experiments.

WT- and $\Delta \mathrm{m} 4+\mathrm{m} 6+\mathrm{m} 152-\mathrm{MCMV}$

The purpose of these experiments was to ask: when we are at the threshold of virus infectivity (i.e. when not all mice are infected) and when virus is delivered by a natural route of infection, do the MHC class I immune evasion genes impact the ability of the virus to establish infection? A secondary question was: do these genes impact virus titres or the size of the immune response in acute or chronic infection?

Individual cohorts of mice were infected and analyzed at different times p.i.: seven days (peak CD8 T cell response), 21 days (peak titres in the salivary gland), and 13 weeks (for the chronic CD8 T cell response). The results for infection of adult BALB/c mice with 1,000 pfu of WT- or $\Delta \mathrm{m} 4+\mathrm{m} 6+\mathrm{m} 152-\mathrm{MCMV}$ by different routes of immunization are summarized in Table 1 , and the results for $\mathrm{B} 6$ mice are shown in Table 2. Only the data for infection with $1,000 \mathrm{pfu}$ is shown because this dose gave a higher rate of 
Table 1 Comparison of 1,000 pfu WT- and $\Delta \mathrm{m} 4+\mathrm{m} 6+\mathrm{m} 152-\mathrm{MCMV}$ infection of BALB/c mice by various routes based on the CD8 T cell and antibody response and salivary gland titres

\begin{tabular}{|c|c|c|c|c|c|c|}
\hline \multirow[t]{2}{*}{ Intraperitoneal $^{\mathrm{a}}$} & \multicolumn{2}{|l|}{7 days ${ }^{b}$} & \multicolumn{2}{|l|}{21 days } & \multicolumn{2}{|l|}{13 weeks } \\
\hline & WT & $\mathrm{TKO}^{\mathrm{c}}$ & WT & $\mathrm{TKO}$ & WT & $\mathrm{TKO}$ \\
\hline \multirow[t]{2}{*}{ Number of mice with SG virus ${ }^{\mathrm{d}}$} & $1 / 2$ & $0 / 5$ & 1) $1 / 6^{\mathrm{f}}$ & 1) $6 / 6$ & $3 / 5$ & $5 / 6$ \\
\hline & & & 2) $6 / 6$ & 2) $6 / 6$ & & \\
\hline \multirow[t]{2}{*}{ Average titre in $\mathrm{SG}^{\mathrm{e}}$} & $100 \pm 0$ & 0 & 1) $300 \pm 0$ & 1) $1,000 \pm 880$ & $400 \pm 265$ & $420 \pm 377$ \\
\hline & & & 2) $1,430 \pm 763$ & 2) $1,150 \pm 644$ & & \\
\hline CTL response ${ }^{g}$ & $6 / 6$ & $1 / 1$ & $6 / 6$ & $6 / 6$ & $6 / 6$ & $5 / 6$ \\
\hline$\% \mathrm{IFN} \gamma^{+} \mathrm{CD} 8^{+} \mathrm{T}$ cells & $0.54 \pm 0.3$ & $0.22 \pm 0$ & $2.51 \pm 0.47$ & $1.45 \pm 0.42$ & $3.37 \pm 0.97$ & $1.11 \pm 0.59$ \\
\hline \multirow[t]{2}{*}{ Seropositivity $^{\mathrm{h}}$} & $0 / 6$ & $0 / 6$ & 1) $0 / 6$ & 1) $0 / 6$ & $6 / 6$ & $3 / 5$ \\
\hline & & & 2) $6 / 6$ & 2) $4 / 6$ & & \\
\hline \multicolumn{7}{|l|}{ Subcutaneous } \\
\hline \multirow[t]{2}{*}{ Number of mice with SG virus } & $0 / 6$ & $0 / 6$ & 1) $2 / 6$ & 1) $0 / 5$ & $0 / 4$ & $1 / 6$ \\
\hline & & & 2) $2 / 6$ & 2) $0 / 6$ & & \\
\hline \multirow[t]{2}{*}{ Average titre in SG } & 0 & 0 & 1) $350 \pm 70.7$ & 1) 0 & 0 & $20 \pm 0$ \\
\hline & & & 2) $700 \pm 0$ & 2) 0 & & \\
\hline \multirow[t]{2}{*}{ CTL response } & $0 / 6$ & $0 / 6$ & 1) $6 / 6$ & 1) $5 / 5$ & $4 / 4$ & $6 / 6$ \\
\hline & & & 2) $6 / 6$ & 2) $6 / 6$ & & \\
\hline \multirow[t]{2}{*}{$\% \mathrm{IFN} \gamma^{+} \mathrm{CD} 8^{+} \mathrm{T}$ cells } & $0.1 \pm 0.09$ & $0.07 \pm 0.04$ & 1) $3.5 \pm 1.14$ & 1) $1.28 \pm 0.59$ & $1.49 \pm 0.51$ & $0.88 \pm 0.61$ \\
\hline & & & 2) $6.12 \pm 1.68$ & 2) $3.49 \pm 4.22$ & & \\
\hline Seropositivity & $0 / 6$ & $0 / 6$ & N.D. ${ }^{i}$ & N.D. & $3 / 5$ & $2 / 6$ \\
\hline \multicolumn{7}{|l|}{ Intranasal } \\
\hline Number of mice with SG virus & N.D. & N.D. & $0 / 6$ & $0 / 6$ & $3 / 6$ & $2 / 6$ \\
\hline Average titre in SG & N.D. & N.D. & 0 & 0 & $4,470 \pm 1,360$ & $1,050 \pm 495$ \\
\hline CTL response & N.D. & N.D. & $2 / 6$ & $2 / 6$ & $5 / 6$ & $3 / 5$ \\
\hline$\% \mathrm{IFN} \gamma^{+} \mathrm{CD} 8^{+} \mathrm{T}$ cells & N.D. & N.D. & $0.87 \pm 0.88$ & $0.68 \pm 0.62$ & $1.15 \pm 0.77$ & $0.28 \pm 0.31$ \\
\hline Seropositivity & N.D. & N.D. & $0 / 6$ & $0 / 6$ & $4 / 6$ & $0 / 6$ \\
\hline
\end{tabular}

${ }^{a}$ Mice were infected i.p., s.c. (at the nape of the neck), or i.n. Virus was diluted to 1,000 pfu in a total volume of $200 \mu \mathrm{L}$ for i.p. and s.c. infection; for i.n. administration, $10 \mu \mathrm{L}$ were instilled in each nare

${ }^{\mathrm{b}}$ On the indicated day p.i., mice were sacrificed, salivary glands harvested and $500 \mu \mathrm{L}$ of blood taken for sera and peripheral blood mononuclear cells (PBMC)

c $\mathrm{TKO}=$ the "triple knockout virus" $\Delta \mathrm{m} 4+\mathrm{m} 6+\mathrm{m} 152-\mathrm{MCMV}$

d $10 \%$ salivary gland (SG) homogenates were prepared in DMEM (10\% FCS, supplemented with penicillin and streptomycin) and assayed for virus by a standard plaque assay on BALB 3 T3 fibroblasts. The number of mice with salivary gland virus over the total number of mice per group is listed. The limit of detection is $100 \mathrm{pfu}$

e The average only includes mice that had salivary gland present \pm standard deviation

${ }^{\mathrm{f}}$ Experiments under the exact same conditions performed on different days are shown individually to demonstrate experiment-to-experiment variation

g The cytotoxic T cell (CTL) response to the IEI/pp89 antigen was measured from PBMC after red blood cell (RBC) lysis by intracellular cytokine staining for IFN- $\gamma$ and analyzed on an LSR II flow cytometer, as described [58]. The ratio of mice with a positive CTL response to the total number of mice per group is listed. The average \% of IFN $\gamma^{+} \mathrm{CD} 8^{+} \mathrm{T}$ cells is also listed, taken from the mice with positive responses only. CD8 $\mathrm{T}$ cell responses were only considered positive if background was $\leq 0.2 \%$ and the IE1/pp 89 response was $\geq 2 \mathrm{X}$ background

${ }^{\mathrm{h}}$ Antibody to MCMV was assayed by ELISA using MCMV- or mock-infected cell lysate as a plate antigen. Serostatus was determined from a 1:100 dilution of straight sera and was considered positive if it was $\geq 1.5 \mathrm{X}$ background. The ratio of mice with positive sera to the total number of mice per group is listed

${ }^{\mathrm{i}}$ N.D. not done

infection across all routes, and, interestingly, there was no consistent dose titration effect. Infection with $100 \mathrm{pfu}$ did not change the overall conclusions, and that data is incorporated into the accumulated results to be discussed later.
Table 3 summarizes a separate set of experiments in which neonatal mice were infected orally.

The overall impression from these experiments was that the immune evasion genes did not impact the ability to 
Table 2 Comparison of 1,000 pfu WT- and $\Delta \mathrm{m} 4+\mathrm{m} 6+\mathrm{m} 152-\mathrm{MCMV}$ infection of C57BL/6 mice by various routes based on the CD8 T cell and antibody response and salivary gland titres

\begin{tabular}{|c|c|c|c|c|c|c|}
\hline \multirow[t]{2}{*}{ Intraperitoneal $^{\mathrm{a}}$} & \multicolumn{2}{|l|}{7 days } & \multicolumn{2}{|l|}{21 days } & \multicolumn{2}{|l|}{13 weeks } \\
\hline & WT & TKO & WT & TKO & WT & TKO \\
\hline Number of mice with SG virus & $0 / 4$ & $0 / 5$ & $0 / 4$ & $0 / 1$ & $0 / 3$ & $2 / 5$ \\
\hline Average titre in SG & 0 & 0 & 0 & 0 & 0 & $200 \pm 0$ \\
\hline CTL response & $5 / 6$ & $6 / 6$ & $5 / 6$ & $1 / 6$ & $4 / 5$ & $5 / 6$ \\
\hline$\% \mathrm{IFN} \gamma^{+} \mathrm{CD} 8^{+} \mathrm{T}$ cells & $0.54 \pm 0.29$ & $1.03 \pm 0.80$ & $2.68 \pm 1.57$ & $1.02 \pm 0$ & $2.43 \pm 0.12$ & $4.02 \pm 1.88$ \\
\hline Seropositivity & N.D. & N.D. & $2 / 5$ & $0 / 6$ & $4 / 5$ & $4 / 6$ \\
\hline \multicolumn{7}{|l|}{ Subcutaneous } \\
\hline Number of mice with SG virus & $0 / 6$ & $0 / 6$ & $0 / 6$ & $0 / 6$ & N.D. & N.D. \\
\hline Average titre in SG & 0 & 0 & 0 & 0 & N.D. & N.D. \\
\hline CTL response & $5 / 5$ & $4 / 5$ & $4 / 6$ & $4 / 6$ & N.D. & N.D. \\
\hline$\% \mathrm{IFN} \gamma^{+} \mathrm{CD} 8^{+} \mathrm{T}$ cells & $0.69 \pm 0.38$ & $0.75 \pm 0.47$ & $1.35 \pm 0.69$ & $1.05 \pm 0.34$ & N.D. & N.D. \\
\hline Seropositivity & $0 / 5$ & $0 / 5$ & $3 / 6$ & $0 / 6$ & N.D. & N.D. \\
\hline \multicolumn{7}{|l|}{ Intranasal } \\
\hline Number of mice with SG virus & $0 / 6$ & $0 / 6$ & N.D. & N.D. & $0 / 5$ & $0 / 6$ \\
\hline Average titre in SG & 0 & 0 & N.D. & N.D. & 0 & 0 \\
\hline CTL response & $0 / 6$ & $0 / 6$ & N.D. & N.D. & $2 / 6$ & $0 / 6$ \\
\hline$\% \mathrm{IFN} \gamma^{+} \mathrm{CD} 8^{+} \mathrm{T}$ cells & 0 & 0 & N.D. & N.D. & $2.32 \pm 0.76$ & 0 \\
\hline Seropositivity & $0 / 6$ & $0 / 6$ & N.D. & N.D. & $0 / 5$ & $0 / 6$ \\
\hline
\end{tabular}

${ }^{a}$ Methods are the same as Table 1, except that the CD8 T cell response to the M38 antigen was measured from PBMC

establish infection. Unfortunately, these experiments were plagued by an unexpected degree of variation between cages and between experiments. As an example, there were two experiments in which BALB/c mice were infected i.p. with 1,000 pfu of MCMV and analyzed at 21 days p.i. (see Table 1, route: i.p., time: 21 days). In the first experiment, one of six mice infected with WT-MCMV mounted a CD8 $\mathrm{T}$ cell response, whereas all six of six mice infected with $\Delta \mathrm{m} 4+\mathrm{m} 6+\mathrm{m} 152-\mathrm{MCMV}$ did. In a repeat of that experiment, done a few months later, six of six mice infected with either virus mounted a CD8 T cell response. Similarly, the ability to infect neonates with either virus was highly variable. This degree of variability suggested that there was a factor in these experiments, probably in our mouse colony, that could impact infection and which we could not control. At present we are investigating whether the recently discovered mouse pathogen murine norovirus (MNV), which is present in our mouse colony, could be contributing to this variability. It is possible to achieve statistically meaningful comparisons in such circumstances-either to reveal small differences or to state that the infections are actually statistically similar-but the number of experiments and mice required is prohibitively large.

One way in which we can approach this data is to look at these infections as we would look at human data, where we know that there are many confounding variables, and where we do not know the route, dose, or day of infection. With this in mind, data from these experiments have been analyzed in just this fashion, i.e. pooling the results of the different infectious routes and doses (see Tables 4 and 5). The pooled data is from infected adults only; the neonatal mice were not included. Altogether, we can draw some tentative conclusions:

1. The percentage of mice making a CD8 $\mathrm{T}$ cell response or that were seropositive, was very similar for the two virus infections in both $\mathrm{BALB} / \mathrm{c}$ and $\mathrm{B} 6$ mice. We conclude that there is no evidence to suggest that $\Delta \mathrm{m} 4+\mathrm{m} 6+\mathrm{m} 152-\mathrm{MCMV}$ is impaired in its ability to establish an infection.

2. WT-MCMV appears to be more poorly controlled in the salivary glands in BALB/c mice: virus was detectable in a higher percentage of mice, and the titres of those that were infected were higher in most individual experiments (see Table 1), although the latter trend was not statistically significant. This is consistent with our previous results using high dose i.p. infection. It is interesting that although the percentage of mice that made CD8 T cell responses did not differ between WT- and $\Delta \mathrm{m} 4+\mathrm{m} 6+\mathrm{m} 152-\mathrm{MCMV}$, the overall size of the response tended to be higher in WT-MCMV infection in $\mathrm{BALB} / \mathrm{c}$ mice (Table 1). This might be due to a higher degree of viral activity in BALB/c mice, but a larger sample size is needed to draw any firm conclusions. 
Table 3 Comparison of salivary gland titres in WT- and $\Delta \mathrm{m} 4+\mathrm{m} 6+\mathrm{m} 152-\mathrm{MCMV}$ oral infection of BALB/c pups mice across doses and age at infection

\begin{tabular}{lll}
\hline Number of mice with SG virus $^{\mathrm{a}}$ & WT & TKO $^{\mathrm{c}}$ \\
\hline 21 days (postnatal) $^{\mathrm{d}}$ & 1) $1 / 4^{\mathrm{e}}$ & 1) $2 / 5$ \\
& 2) $0 / 4$ & 2) $0 / 4$ \\
& & 3) $0 / 2$ \\
22 days & 1) $0 / 4$ & 1) $0 / 3$ \\
& 2) $0 / 8^{\mathrm{b}}$ & \\
23 days & 1) $1 / 4$ & 1) $1 / 4$ \\
& 2) $5 / 5$ & 2) $3 / 5$ \\
& 3) $0 / 5^{\mathrm{b}}$ & 3) $0 / 5^{\mathrm{b}}$ \\
24 days & 4) $1 / 9$ & 4) $0 / 10$ \\
& 1) $0 / 3^{\mathrm{b}}$ & 1) $0 / 2^{\mathrm{b}}$ \\
26 days & 2) $2 / 4$ & 2) $0 / 2$ \\
Total number of mice with $S G$ virus & 10/55 & 1) $0 / 6^{\mathrm{b}}$ \\
Average titre & 1) $0 / 5^{\mathrm{b}}$ & $6 / 48$ \\
\end{tabular}

${ }^{a}$ Pups were infected p.o. between postnatal day one and five with either 100 of 1,000 pfu of WT- or $\Delta \mathrm{m} 4+\mathrm{m} 6+\mathrm{m} 152-\mathrm{MCMV}$ in $5 \mu \mathrm{L}$

${ }^{\mathrm{b}}$ Experiments in which pups were infected with 100 pfu MCMV; in all other experiments pups were infected with 1,000 pfu MCMV

c $\mathrm{TKO}=$ the "triple knockout virus" $\Delta \mathrm{m} 4+\mathrm{m} 6+\mathrm{m} 152-\mathrm{MCMV}$

d 21 days p.i., the salivary glands were harvested and $10 \%$ homogenates were prepared in DMEM (10\% FCS, supplemented with penicillin and streptomycin) and assayed for virus by a standard plaque assay on BALB 3 T3 fibroblasts. The ratio of mice with salivary gland virus to the total number of mice per group is listed. The limit of detection is $100 \mathrm{pfu}$

${ }^{\mathrm{e}}$ Experiments under the exact same conditions performed on different days are shown individually to demonstrate experiment-to-experiment variation

${ }^{\mathrm{f}}$ The ratio indicates the total number of mice with salivary gland virus to the total number of mice infected with that virus, combining doses and age at infection

These analyses do suggest that the published data concluding that the MHC class I immune evasion genes do not significantly impact the CD8 $\mathrm{T}$ cell response or virus titres in central organs are not artifacts due to the experimental conditions, such as high dose, i.p. infection. We also note that Verena Böhm from the Reddehase group has analyzed the impact of MHC class I immune evasion in very low dose infection given by the intraplantar route. Those experiments are still ongoing, and may reveal an advantage for WT-MCMV in intranodal gene expression, but with no significant differences in CD8 T cell priming (Matthias J. Reddehase, personal communication). The data presented here also support the notion that, as least in BALB/c mice, the impact of the MHC class I immune evasion genes is on viral control at the site of dissemination.

\section{Discussion}

MCMV-specific CD8 $\mathrm{T}$ cells are better able to control MCMV infection in vitro and in vivo if at least one of the MHC class I immune evasion genes is missing. However, in a fully immunocompetent animal, infection with high dose MCMV or a mutant lacking the three MHC class I immune evasion genes results in the same global CD8 T cell response to the virus. The $\mathrm{CD} 8 \mathrm{~T}$ cell response magnitude and specificity and the amount of virus in different organs is exactly the same in B6 mice. In BALB/c mice, the response is the same except for the titres in the salivary glands, whereby $\Delta \mathrm{m} 4+\mathrm{m} 6+\mathrm{m} 152-\mathrm{MCMV}$ is somewhat better controlled. Under natural infection conditions, the suggestion remains that the MHC class I immune evasion genes provide a survival advantage to the virus in the salivary glands.

We originally considered three main possibilities for the role of the MHC class I immune evasion genes in vivo (see Fig. 1):

1. to allow for better establishment of initial infection

2. to allow the virus to survive in the host after the adaptive immune response has developed

3. to allow for more efficient transmission.

The evidence summarized above does not strongly support the first or second possibility. We know infection is established and that the acute immune response is virtually identical in WT- and $\Delta \mathrm{m} 4+\mathrm{m} 6+\mathrm{m} 152-\mathrm{MCMV}$ infection, over the entire lifetime of an animal. It is not surprising that evasion of the adaptive immune system would have little impact on the initial days of infection, and the redundancy of immune control mechanisms likely ensures that infection will be controlled by at least one arm of the immune response. If both viruses establish latency during the first days of infection, it may be impossible for the immune system to eradicate them [13]. This is particularly so if the viral genome can be maintained and even replicated in host cells without expression of viral proteins, invisible to the immune system until it reactivates. There is evidence, however, that viral proteins are visible to the immune system before full viral reactivation. IE1 epitope-specific CD8 T cells maintain replicative latency by decreasing the prevalence of IE1 transcripts in latently infected lungs [77].

Hence, a more likely scenario is that the MHC class I immune evasion genes may allow reactivating virus to escape immune control and form active foci of reactivation. The sites of and cell types of reactivation (e.g. lung monocytes or endothelial cells) may be unique from the sites of acute infection, and expression or function of the MHC class I immune evasion genes is somewhat cell-type-specific $[65,66]$. Thus, the MHC class I immune evasion genes may not function as effectively at the sites of acute infection 
Table 4 Comparison of WT- and $\Delta \mathrm{m} 4+\mathrm{m} 6+\mathrm{m} 152-\mathrm{MCMV}$ infection of BALB/c mice across all routes and doses based on the CD8 $\mathrm{T}$ cell response and salivary gland titres

\begin{tabular}{|c|c|c|c|c|c|c|}
\hline \multirow[t]{2}{*}{ Combined routes, doses } & \multicolumn{2}{|c|}{7 days } & \multicolumn{2}{|l|}{21 days } & \multicolumn{2}{|l|}{13 weeks } \\
\hline & WT & TKO & WT & TKO & WT & TKO \\
\hline Number of mice with a CTL response & $13 / 23$ & $9 / 19$ & $44 / 54$ & $39 / 53$ & $28 / 34$ & $29 / 34$ \\
\hline Number of mice with SG virus & $4 / 19$ & $0 / 23$ & $29 / 54$ & $19 / 53$ & $20 / 34$ & $9 / 36$ \\
\hline Average SG titre & 100 & 0 & $668 \pm 739$ & $1,014 \pm 732$ & $1,418 \pm 2057$ & $511 \pm 451$ \\
\hline
\end{tabular}

Table 5 Comparison of WTand $\Delta \mathrm{m} 4+\mathrm{m} 6+\mathrm{m} 152-\mathrm{MCMV}$ infection of C57BL/6 mice across all routes and doses based on the CD8 T cell response and salivary gland titres

\begin{tabular}{|c|c|c|c|c|c|c|}
\hline \multirow[t]{2}{*}{ Combined routes, doses } & \multicolumn{2}{|l|}{7 days } & \multicolumn{2}{|c|}{21 days } & \multicolumn{2}{|c|}{13 weeks } \\
\hline & WT & TKO & WT & $\mathrm{TKO}$ & WT & TKO \\
\hline Number of mice with a CTL response & $11 / 17$ & $10 / 17$ & $9 / 12$ & $5 / 12$ & $6 / 11$ & $5 / 12$ \\
\hline Number of mice with SG virus & $0 / 20$ & $0 / 23$ & $0 / 24$ & $0 / 22$ & $0 / 18$ & $2 / 23$ \\
\hline Average SG titre & 0 & 0 & 0 & 0 & 0 & $200 \pm 0$ \\
\hline
\end{tabular}

and may only be able to exert their power in reactivating cells and tissues. In the wild, virus reactivation from time to time leads to replication in the salivary glands.

Finally, the role of the MHC class I immune evasion genes may be to allow for more efficient transmission. The salivary glands are important in MCMV replication and transmission. CD8 T cells and the MHC class I immune evasion genes have an impact on the titres in the salivary glands in immunocompetent animals [76]. Perhaps the genes function here to prevent effective CD8 T cell control.
Infected acinar cells may be particularly sensitive to the MHC class I immune evasion genes, thereby robustly inhibiting CD8 $\mathrm{T}$ cell control. In addition, CD8 T cells may be less effective at killing WT-MCMV-infected acinar cells due to resistance to apoptosis or other unknown mechanisms. Although the mechanism is not known, it does seem that acinar cells are peculiarly resistant to CD8 $\mathrm{T}$ cell control-in contrast to the lungs and liver, CD8 T cells have little impact on WT-MCMV virus replication in these cells. In this scenario, the MHC class I immune evasion genes

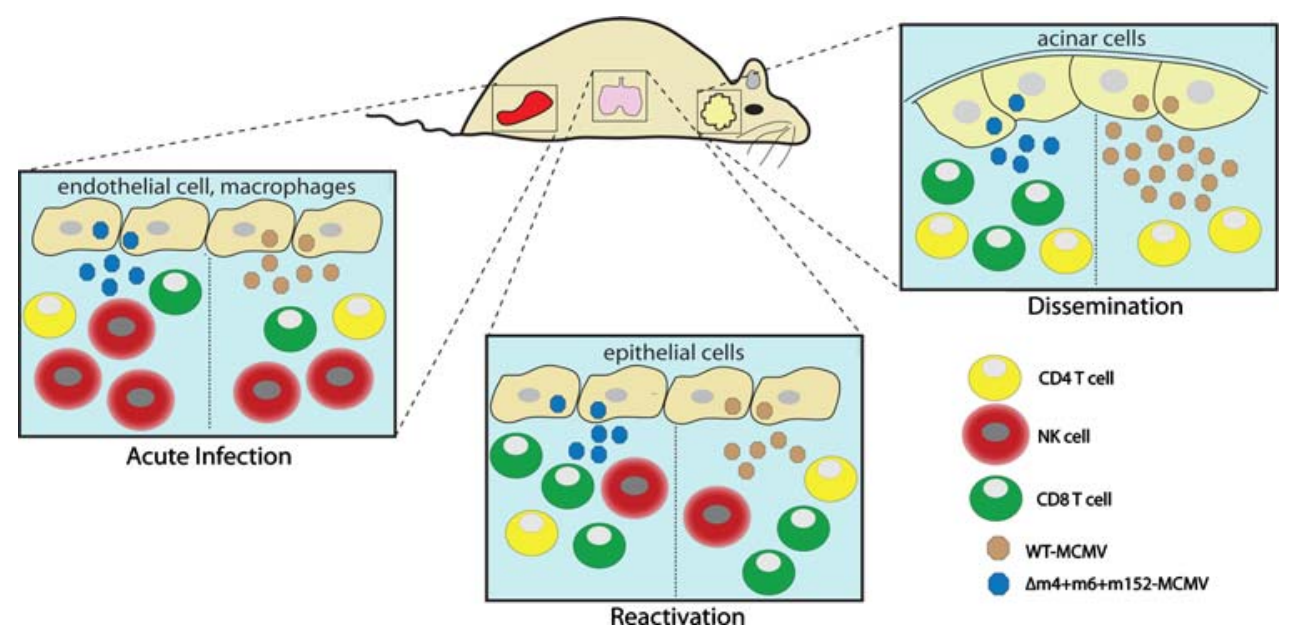

Fig. 1 Model for the role of MHC class I immune evasion genes in MCMV infection in vivo. The three stages of viral infection are shown. Although most organs are infected, acute infection is represented here by the spleen, where NK cells (red) play an important role in controlling the virus. CD8 $\mathrm{T}$ cells (green) and $\mathrm{CD} 4 \mathrm{~T}$ cells (yellow) also impact viral titres in the spleen; however, virus still establishes infection in the face of these different forms of cellular control. The acute viral pool is the same in WT-MCMV (brown) and $\Delta \mathrm{m} 4+\mathrm{m} 6+\mathrm{m} 152-$ MCMV (blue) infection, as evidenced by the magnitude of the CD8 $\mathrm{T}$ cell response and viral titres. The viral load in acute infection determines the latent pool of virus, shown in the lung as a representa- tive organ. In the lung, CD8 T cells are particularly important in controlling virus titres in the bone marrow transplant model. WT- and $\Delta \mathrm{m} 4+\mathrm{m} 6+\mathrm{m} 152-\mathrm{MCMV}$ levels are also the same based on the magnitude of the CD8 $\mathrm{T}$ cell response and viral titres. Finally, in the third stage of infection, virus traffics to the salivary glands, replicates, and transmits to a new host. In the salivary glands, both CD8 and CD4 T cells are important for virus control. In immunocompetent BALB/c mice, CD8 T cells differentially control $\Delta \mathrm{m} 4+\mathrm{m} 6+\mathrm{m} 152-\mathrm{MCMV}$, suggesting a role for the MHC class I immune evasion genes in facilitating viral spread 
would simply allow for effective dissemination, and therefore increased viral fitness, by impairing the cytotoxic function of CD8 T cells enough to impact control of virus in this organ, but not enough to disrupt its global equilibrium in the host (see also the contribution by Campbell et al. in this issue of MMI).

The evolution of pathogens is often thought of in terms of a competition between the virus and the host immune system. It would be prudent to also consider competitive evolution between viruses-perhaps the MHC class I immune evasion genes have been conserved simply because MCMV is constantly competing with itself. It is clear that many individuals are infected with multiple CMV strains, and it has been suggested that the immune evasion genes' main role may be to allow for superinfection [18, 78] (Klaus Fruh and Colin Powers, personal communication). The many identified strains of MCMV and the incidence of natural superinfection points to a constant pressure for one strain to outcompete another. As nicely put in a commentary by Stephen Hedrick, "A zebra does not have to outrun the lion, just the slowest member of the herd" [79]. And in such an environment, the most evasive virus would win.

Acknowledgments This work was supported by grants from the NIH AI047206 and AI0570099.

\section{References}

1. Smith MG (1954) Propagation of salivary gland virus of the mouse in tissue cultures. Proc Soc Exp Biol Med 86:435-440

2. Singleton GR, Smith AL, Shellam GR, Fitzgerald N, Muller WJ (1993) Prevalence of viral antibodies and helminths in field populations of house mice (Mus domesticus) in southeastern Australia. Epidemiol Infect 110:399-417

3. Singleton GR, Smith AL, Krebs CJ (2000) The prevalence of viral antibodies during a large population fluctuation of house mice in Australia. Epidemiol Infect 125:719-727

4. Moro D, Lloyd ML, Smith AL, Shellam GR, Lawson MA (1999) Murine viruses in an island population of introduced house mice and endemic short-tailed mice in Western Australia. J Wildl Dis 35:301-310

5. Gorman S, Harvey NL, Moro D, Lloyd ML, Voigt V, Smith LM, Lawson MA, Shellam GR (2006) Mixed infection with multiple strains of murine cytomegalovirus occurs following simultaneous or sequential infection of immunocompetent mice. J Gen Virol $87: 1123-1132$

6. Booth TW, Scalzo AA, Carrello C, Lyons PA, Farrell HE, Singleton GR, Shellam GR (1993) Molecular and biological characterization of new strains of murine cytomegalovirus isolated from wild mice. Arch Virol 132:209-220

7. Farroway LN, Gorman S, Lawson MA, Harvey NL, Jones DA, Shellam GR, Singleton GR (2005) Transmission of two Australian strains of murine cytomegalovirus (MCMV) in enclosure populations of house mice (Mus domesticus). Epidemiol Infect 133:701-710

8. Pollock JL, Virgin HWt (1995) Latency, without persistence, of murine cytomegalovirus in the spleen and kidney. J Virol 69:1762-1768
9. Kurz S, Steffens HP, Mayer A, Harris JR, Reddehase MJ (1997) Latency versus persistence or intermittent recurrences: evidence for a latent state of murine cytomegalovirus in the lungs. J Virol 71:2980-2987

10. Koffron AJ, Hummel M, Patterson BK, Yan S, Kaufman DB, Fryer JP, Stuart FP, Abecassis MI (1998) Cellular localization of latent murine cytomegalovirus. J Virol 72:95-103

11. Mercer JA, Spector DH (1986) Pathogenesis of acute murine cytomegalovirus infection in resistant and susceptible strains of mice. J Virol 57:497-504

12. Henson D, Strano AJ (1972) Mouse cytomegalovirus. Necrosis of infected and morphologically normal submaxillary gland acinar cells during termination of chronic infection. Am J Pathol 68:183202

13. Reddehase MJ, Balthesen M, Rapp M, Jonjic S, Pavic I, Koszinowski UH (1994) The conditions of primary infection define the load of latent viral genome in organs and the risk of recurrent cytomegalovirus disease. J Exp Med 179:185-193

14. Reddehase MJ, Weiland F, Munch K, Jonjic S, Luske A, Koszinowski UH (1985) Interstitial murine cytomegalovirus pneumonia after irradiation: characterization of cells that limit viral replication during established infection of the lungs. J Virol 55:264-273

15. Koffron AJ, Mueller KH, Kaufman DB, Stuart FP, Patterson B, Abecassis MI (1995) Direct evidence using in situ polymerase chain reaction that the endothelial cell and T-lymphocyte harbor latent murine cytomegalovirus. Scand J Infect Dis Suppl 99:61-62

16. Pollock JL, Presti RM, Paetzold S, Virgin HWt (1997) Latent murine cytomegalovirus infection in macrophages. Virology 227:168-179

17. Jonjic S, Pavic I, Polic B, Crnkovic I, Lucin P, Koszinowski UH (1994) Antibodies are not essential for the resolution of primary cytomegalovirus infection but limit dissemination of recurrent virus. J Exp Med 179:1713-1717

18. Gold MC, Munks MW, Wagner M, McMahon CW, Kelly A, Kavanagh DG, Slifka MK, Koszinowski UH, Raulet DH, Hill AB (2004) Murine cytomegalovirus interference with antigen presentation has little effect on the size or the effector memory phenotype of the CD8 T cell response. J Immunol 172:6944-6953

19. Arase H, Mocarski ES, Campbell AE, Hill AB, Lanier LL (2002) Direct recognition of cytomegalovirus by activating and inhibitory NK cell receptors. Science 296:1323-1326

20. Smith HR, Heusel JW, Mehta IK, Kim S, Dorner BG, Naidenko OV, Iizuka K, Furukawa H, Beckman DL, Pingel JT et al (2002) Recognition of a virus-encoded ligand by a natural killer cell activation receptor. Proc Natl Acad Sci USA 99:8826-8831

21. Shellam GR, Flexman JP (1986) Genetically determined resistance to murine cytomegalovirus and herpes simplex virus in newborn mice. J Virol 58:152-156

22. Quinnan GVJ, Manischewitz JF (1987) Genetically determined resistance to lethal murine cytomegalovirus infection is mediated by interferon-dependent and -independent restriction of virus replication. J Virol 61:1875-1881

23. Allan JE, Shellam GR (1984) Genetic control of murine cytomegalovirus infection: virus titres in resistant and susceptible strains of mice. Arch Virol 81:139-150

24. Scalzo AA, Fitzgerald NA, Wallace CR, Gibbons AE, Smart YC, Burton RC, Shellam GR (1992) The effect of the Cmv-1 resistance gene, which is linked to the natural killer cell gene complex, is mediated by natural killer cells. J Immunol 149:581-589

25. Katzenstein DA, Yu GS, Jordan MC (1983) Lethal infection with murine cytomegalovirus after early viral replication in the spleen. J Infect Dis 148:406-411

26. Krmpotic A, Busch DH, Bubic I, Gebhardt F, Hengel H, Hasan M, Scalzo AA, Koszinowski UH, Jonjic S (2002) MCMV glycoprotein gp40 confers virus resistance to CD8+ T cells and NK cells in vivo. Nat Immunol 3:529-535 
27. Iizuka K, Nakajima C, Iizuka YM, Takase M, Kato T, Noda S, Tanaka K, Kanagawa O (2007) Protection from lethal infection by adoptive transfer of CD8 T cells genetically engineered to express virus-specific innate immune receptor. J Immunol 179:1122-1128

28. Scalzo AA, Lyons PA, Fitzgerald NA, Forbes CA, Shellam GR (1995) The BALB.B6-Cmv1r mouse: a strain congenic for Cmv1 and the NK gene complex. Immunogenetics 41:148-151

29. Lathbury LJ, Allan JE, Shellam GR, Scalzo AA (1996) Effect of host genotype in determining the relative roles of natural killer cells and $\mathrm{T}$ cells in mediating protection against murine cytomegalovirus infection. J Gen Virol 77:2605-2613

30. Bukowski JF, Woda BA, Welsh RM (1984) Pathogenesis of murine cytomegalovirus infection in natural killer cell-depleted mice. J Virol 52:119-128

31. Shanley JD (1990) In vivo administration of monoclonal antibody to the NK 1.1 antigen of natural killer cells: effect on acute murine cytomegalovirus infection. J Med Virol 30:58-60

32. Welsh RM, Brubaker JO, Vargas-Cortes M, O’Donnell CL (1991) Natural killer (NK) cell response to virus infections in mice with severe combined immunodeficiency. The stimulation of NK cells and the NK cell-dependent control of virus infections occur independently of T and B cell function. J Exp Med 173:1053-1063

33. Lawson CM, Grundy JE, Shellam GR (1988) Antibody responses to murine cytomegalovirus in genetically resistant and susceptible strains of mice. J Gen Virol 69:1987-1998

34. Tolpin MD, Starr SE, Arbeter AM, Plotkin SA (1980) Inactivated mouse cytomegalovirus vaccine: preparation, immunogenicity, and protective effect. J Infect Dis 142:569-574

35. Farrell HE, Shellam GR (1991) Protection against murine cytomegalovirus infection by passive transfer of neutralizing and nonneutralizing monoclonal antibodies. J Gen Virol 72:149-156

36. Rapp M, Messerle M, Buhler B, Tannheimer M, Keil GM, Koszinowski UH (1992) Identification of the murine cytomegalovirus glycoprotein B gene and its expression by recombinant vaccinia virus. J Virol 66:4399-4406

37. Xu J, Lyons PA, Carter MD, Booth TW, Davis-Poynter NJ, Shellam GR, Scalzo AA (1996) Assessment of antigenicity and genetic variation of glycoprotein B of murine cytomegalovirus. J Gen Virol 77:49-59

38. Geoffroy F, Moachon N, Rodwell J, Quash GA (1996) Murine cytomegalovirus inactivated by sodium periodate is innocuous and immunogenic in mice and protects them against death and infection. Vaccine 14:1686-1694

39. Polic B, Hengel H, Krmpotic A, Trgovcich J, Pavic I, Luccaronin P, Jonjic S, Koszinowski UH (1998) Hierarchical and redundant lymphocyte subset control precludes cytomegalovirus replication during latent infection. J Exp Med 188:1047-1054

40. Jonjic S, Mutter W, Weiland F, Reddehase MJ, Koszinowski UH (1989) Site-restricted persistent cytomegalovirus infection after selective long-term depletion of CD4+ T lymphocytes. J Exp Med 169:1199-1212

41. Jonjic S, Pavic I, Lucin P, Rukavina D, Koszinowski UH (1990) Efficacious control of cytomegalovirus infection after long-term depletion of CD8+ T lymphocytes. J Virol 64:5457-5464

42. Koszinowski UH (1991) Molecular aspects of immune recognition of cytomegalovirus. Transplant Proc 23:70-73, discussion 74

43. Reddehase MJ, Jonjic S, Weiland F, Mutter W, Koszinowski UH (1988) Adoptive immunotherapy of murine cytomegalovirus adrenalitis in the immunocompromised host: CD4-helper-independent antiviral function of CD8-positive memory $\mathrm{T}$ lymphocytes derived from latently infected donors. J Virol 62:1061-1065

44. Alterio de Goss M, Holtappels R, Steffens HP, Podlech J, Angele P, Dreher L, Thomas D, Reddehase MJ (1998) Control of cytomegalovirus in bone marrow transplantation chimeras lacking the prevailing antigen-presenting molecule in recipient tissues rests primarily on recipient-derived CD8 T cells. J Virol 72:7733-7744
45. Reddehase MJ, Mutter W, Munch K, Buhring HJ, Koszinowski UH (1987) CD8-positive T lymphocytes specific for murine cytomegalovirus immediate-early antigens mediate protective immunity. J Virol 61:3102-3108

46. Koszinowski UH, Reddehase MJ, Keil GM, Volkmer H, Jonjic S, Messerle M, del Val M, Mutter W, Munch K, Buhler B (1987) Molecular analysis of herpesviral gene products recognized by protective cytolytic T lymphocytes. Immunol Lett 16:185-192

47. Holtappels R, Podlech J, Pahl-Seibert MF, Julch M, Thomas D, Simon CO, Wagner M, Reddehase MJ (2004) Cytomegalovirus misleads its host by priming of CD8 T cells specific for an epitope not presented in infected tissues. J Exp Med 199:131-136

48. Fitzgerald NA, Papadimitriou JM, Shellam GR (1990) Cytomegalovirus-induced pneumonitis and myocarditis in newborn mice. A model for perinatal human cytomegalovirus infection. Arch Virol $115: 75-88$

49. Fitzgerald NA, Shellam GR (1991) Host genetic influences on fetal susceptibility to murine cytomegalovirus after maternal or fetal infection. J Infect Dis 163:276-281

50. Grundy JE, Mackenzie JS, Stanley NF (1981) Influence of H-2 and non- $\mathrm{H}-2$ genes on resistance to murine cytomegalovirus infection. Infect Immun 32:277-286

51. Shellam GR, Flexman JP, Farrell HE, Papadimitriou JM (1985) The genetic background modulates the effect of the beige gene on susceptibility to cytomegalovirus infection in mice. Scand $\mathrm{J}$ Immunol 22:147-155

52. Bukowski JF, Warner JF, Dennert G, Welsh RM (1985) Adoptive transfer studies demonstrating the antiviral effect of natural killer cells in vivo. J Exp Med 161:40-52

53. Krmpotic A, Messerle M, Crnkovic-Mertens I, Polic B, Jonjic S, Koszinowski UH (1999) The immunoevasive function encoded by the mouse cytomegalovirus gene $\mathrm{m} 152$ protects the virus against T cell control in vivo. J Exp Med 190:1285-1296

54. Reusch U, Muranyi W, Lucin P, Burgert HG, Hengel H, Koszinowski UH (1999) A cytomegalovirus glycoprotein re-routes MHC class I complexes to lysosomes for degradation. EMBO J 18:1081-1091

55. Ziegler H, Thale R, Lucin P, Muranyi W, Flohr T, Hengel H, Farrell H, Rawlinson W, Koszinowski UH (1997) A mouse cytomegalovirus glycoprotein retains MHC class I complexes in the ERGIC/cis-Golgi compartments. Immunity 6:57-66

56. Wagner M, Gutermann A, Podlech J, Reddehase MJ, Koszinowski UH (2002) Major histocompatibility complex class I allele-specific cooperative and competitive interactions between immune evasion proteins of cytomegalovirus. J Exp Med 196:805-816

57. Holtappels R, Gillert-Marien D, Thomas D, Podlech J, Deegen P, Herter S, Oehrlein-Karpi SA, Strand D, Wagner M, Reddehase MJ (2006) Cytomegalovirus encodes a positive regulator of antigen presentation. J Virol 80:7613-7624

58. Pinto AK, Munks MW, Koszinowski UH, Hill AB (2006) Coordinated function of murine cytomegalovirus genes completely inhibits CTL lysis. J Immunol 177:3225-3234

59. Gold MC, Munks MW, Wagner M, Koszinowski UH, Hill AB, Fling SP (2002) The murine cytomegalovirus immunomodulatory gene $\mathrm{m} 152$ prevents recognition of infected cells by M45-specific CTL but does not alter the immunodominance of the M45-specific CD8 T cell response in vivo. J Immunol 169:359-365

60. Munks MW, Gold MC, Zajac AL, Doom CM, Morello CS, Spector DH, Hill AB (2006) Genome-wide analysis reveals a highly diverse CD8 T cell response to murine cytomegalovirus. J Immunol 176:3760-3766

61. Reddehase MJ, Koszinowski UH (1984) Significance of herpesvirus immediate early gene expression in cellular immunity to cytomegalovirus infection. Nature 312:369-371

62. Reddehase MJ, Fibi MR, Keil GM, Koszinowski UH (1986) Latephase expression of a murine cytomegalovirus immediate-early 
antigen recognized by cytolytic T lymphocytes. J Virol 60:11251129

63. Holtappels R, Grzimek NK, Simon CO, Thomas D, Dreis D, Reddehase MJ (2002) Processing and presentation of murine cytomegalovirus pORFm164-derived peptide in fibroblasts in the face of all viral immunosubversive early gene functions. J Virol 76:60446053

64. Pinto AK, Jamieson AM, Raulet DH, Hill AB (2007) The role of NKG2D signaling in inhibition of cytotoxic T-lymphocyte lysis by the Murine cytomegalovirus immunoevasin $\mathrm{m} 152 / \mathrm{gp} 40$. J Virol 81:12564-12571

65. LoPiccolo DM, Gold MC, Kavanagh DG, Wagner M, Koszinowski UH, Hill AB (2003) Effective inhibition of K(b)- and D(b)-restricted antigen presentation in primary macrophages by murine cytomegalovirus. J Virol 77:301-308

66. Hengel H, Reusch U, Geginat G, Holtappels R, Ruppert T, Hellebrand E, Koszinowski UH (2000) Macrophages escape inhibition of major histocompatibility complex class I-dependent antigen presentation by cytomegalovirus. J Virol 74:7861-7868

67. Kavanagh DG, Gold MC, Wagner M, Koszinowski UH, Hill AB (2001) The multiple immune-evasion genes of murine cytomegalovirus are not redundant: $\mathrm{m} 4$ and $\mathrm{m} 152$ inhibit antigen presentation in a complementary and cooperative fashion. J Exp Med 194:967-978

68. del Val M, Hengel H, Hacker H, Hartlaub U, Ruppert T, Lucin P, Koszinowski UH (1992) Cytomegalovirus prevents antigen presentation by blocking the transport of peptide-loaded major histocompatibility complex class I molecules into the medial-Golgi compartment. J Exp Med 176:729-738

69. Smith LM, Shellam GR, Redwood AJ (2006) Genes of murine cytomegalovirus exist as a number of distinct genotypes. Virology 352:450-465

70. Munks MW, Cho KS, Pinto AK, Sierro S, Klenerman P, Hill AB (2006) Four distinct patterns of memory CD8 T cell responses to chronic murine cytomegalovirus infection. J Immunol 177:450-458
71. Holtappels R, Pahl-Seibert MF, Thomas D, Reddehase MJ (2000) Enrichment of immediate-early 1 (m123/pp89) peptide-specific CD8 T cells in a pulmonary CD62L(lo) memory-effector cell pool during latent murine cytomegalovirus infection of the lungs. J Virol 74:11495-11503

72. Karrer U, Sierro S, Wagner M, Oxenius A, Hengel H, Koszinowski U, Phillips RE, Klenerman P (2003) Memory inflation: continuous accumulation of antiviral CD8+ T cells over time. J Immunol 171:3895

73. Karrer U, Sierro S, Wagner M, Oxenius A, Hengel H, Koszinowski UH, Phillips RE, Klenerman P (2003) Memory inflation: continuous accumulation of antiviral CD8 $+\mathrm{T}$ cells over time. $\mathrm{J}$ Immunol 170:2022-2029

74. Munks MW, Pinto AK, Doom CM, Hill AB (2007) Viral interference with antigen presentation does not alter acute or chronic CD8 $\mathrm{T}$ cell immunodominance in murine cytomegalovirus infection. $\mathrm{J}$ Immunol 178:7235-7241

75. Reddehase MJ, Simon CO, Podlech J, Holtappels R (2004) Stalemating a clever opportunist: lessons from murine cytomegalovirus. Hum Immunol 65:446-455

76. Lu X, Pinto AK, Kelly AM, Cho KS, Hill AB (2006) Murine cytomegalovirus interference with antigen presentation contributes to the inability of CD8 T cells to control virus in the salivary gland. J Virol 80:4200-4202

77. Simon CO, Holtappels R, Tervo HM, Bohm V, Daubner T, Oehrlein-Karpi SA, Kuhnapfel B, Renzaho A, Strand D, Podlech J et al (2006) CD8 T cells control cytomegalovirus latency by epitopespecific sensing of transcriptional reactivation. J Virol 80:1043610456

78. Cicin-Sain L, Podlech J, Messerle M, Reddehase MJ, Koszinowski UH (2005) Frequent coinfection of cells explains functional in vivo complementation between cytomegalovirus variants in the multiply infected host. J Virol 79:9492-9502

79. Hedrick SM (2004) The acquired immune system: a vantage from beneath. Immunity 21:607-615 